\title{
Assessment of the Phytochemical, Proximate, Mineral and Heavy metal constituents of some grass straws used in cultivating Pleurotus ostreatus var florida Eger.
}

\author{
* Okwulehie, Ikechukwu Cyriacus and Okoro Chibueze E. \\ Department of Plant Science and Biotechnology, Michael Okpara University of Agriculture, Umudike, P.M.B. \\ 7267, Umuahia, Abia State, Nigeria.
}

\begin{abstract}
The proximate, phytochemical, mineral and heavy metal contents of the straws of Andropogon gayanus, Panicum maximum, Pennisetum purpurea and Oryza sativa were investigated. The straws contained different levels of crude alkaloids, (0.25 $\pm 0.03-0.05 \pm 0.014)$, flavonoids, $(0.25 \pm 0.024-0.09 \pm 0.024)$, Hydrogen cyanide (HCN) (4.18 $\pm 0.03 \%-2.59 \pm 0.09 \%)$ phenols, $(0.16 \pm 0.001 \%-0.013 \pm 0.007 \%)$, saponins, $(0.37 \pm 0.014 \%$ $0.13 \pm 0.014 \%$ and tannins, $(0.27 \pm 0.002 \%-0.137 \pm 0.001 \%)$. The nutrient content of the straws also varied and ranged as Carbohydrate (CHO), 30.13 \pm 13 in Andropogon straw (ANS), to 27..49 \pm 1.26 in Panicum straw (PAS), Protein, $17.74 \pm 0.47$ in ANS to $13.07 \pm 0.22$ in PAS, Fats, $1.86 \pm 0.02$ in ANS to $0.53 \pm 0.02$ in Oryza straw (ORS), ASH, $5.49 \pm 0.097$ in Pennisetum straw (PES) to $3.83 \pm 0.12$ in PAS, Fibre, $49.74 \pm 1.97$ in PAS to $41.33 \pm 0.15$ in PES, Moisture, $9.33 \pm 0.02$ in PES to $5.15 \pm 0.03$ in PAS to $5.0 \pm 0.09$ in ORS. The mineral composition of the straws (mg/100g) ranged as follows, Calcium: $305.94 \pm 2.35$ in ANS to 203.072 \pm 2.32 in

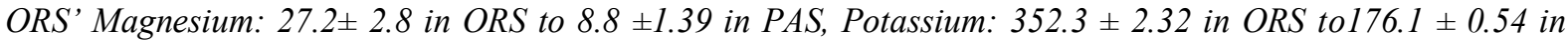
PAS, Sodium: $12.67 \pm 0.58$ in ORS to $9.2 \pm 02$ in ANS, Phosphorus: $233.47 \pm 1.63$ in PES to $158.09 \pm 05$ in ANS. For heavy metals Andropogon traw contained the highest ppmCadmium (7.18), Zinc, (25.08), Lead, (8.44), and copper, (9.96), than the other straws. Oryza straw contained next highest of zinc, but lead was not present. The result of the investigations were discussed in relation of the usefulness of the straws in the cultivation of the edible mushroom Pleurotus ostreatus var florida.
\end{abstract}

Keywords: Grain crop straw, Nutrient composition, bioactive composition, cultivation of mushrooms.

Abbreviations: $A N S=$ Andropogon gayanus, $P A S:=$ Panicum maximum, $P E S=$ Pennisetum purpurea, $O R S=$ Oryza sativa, $\mathrm{CHO}=$ Carbohdrate.

\section{Introduction}

Cereal Grain crops) straws are the most common agricultural wastes used in the cultivation of mushrooms. This category of waste is of limited use and may constitute a form of environmental hazard if not disposed (Okwulehie and Okwujiako 2008). They could however be usedin animal fedding either untreated or urea-treated. An efficient and economical way of disposing these straws is by upgrading them into a high value product for man and the soil by using them to grow mushrooms. The process turns the wastes into edible biomass by solid-state fermentation (Okwujiako, 1992). When the straws are degraded, by the mushroom, useful nutrients are absorbed while the spent-straw serves as organic source of nutrient for crop production. Many researchers have investigated the potentials of achieving this by carrying out trials with different agro-wastes, banana leaves, corn cob, cottons wastes and rice straws to grow Pleurotus tuber-regium (Fasidi and Ekuere (1993)). Wheat straws has a potential of being utilized for commercial products of scleraotia of P. tuber-regium. (Okwujiako and smith (1999). Cotton waste, cassava peels and rice straw supported the frutification of Volvariella esculenta (Fasidi (1996). Royse (2003) used cotton hull and wheat straw to produce Pleurotus species. Sharma, (2003) reported that in general, Pleurotus species grow well on substrates such as paddy (rice) straw, wheat straws, maize stalks and sugar-cane leaves. Similarly Okwulehie and Okwujiako (2008) used the straws of Andropogon gayanus, Panicium maximum, Pennisetum purpurea and Oryza sativa and reported that all the straws supported the growth of Pleurotus ostreatus var florida. Among the straws tested by Okwulehie and Okwujiako(2008). Andropogon gayanus produced significantly higher number of fruiting-bodies of Pleurotus ostreatus var florida than the other straws howeverPanicum maximum straw yielded the least and the lightest fruit-bodies.

Chiejina et al (2010), used fermented saw dust, fermented oil palm fruit fibre and mixtures of the fermented substrates with top-soil or river sand and obtained appreciable yield of Pleurotus tuber-regium fruitbody and sclerotia. Similarly Badu et al (2012), produced fruit-bodies of Pleurotus ostreatus using saw-dust of Ciba pentandra, Terminalia superb and Triplochiton scleroxylon. Badu et al., also investigated the effects of the saw-dust on the quality of the mushrooms produced. 
Some authors have investigated the nutritional and chemical contents of the substrates used to produce the mushroom fruit-bodies and sclerotia so as to determine their influence in the yield and quality of the mushrooms. For instance Badu et al (2012), that the yield and quality of the Oyster mushroom the produced on saw-dust depended on the chemical content of the substrates used. According to Badu et al. 2012, Triplochiton scleroxylon which contained more nutrients gave the best yield of Pleurotus ostreatus.

In previous investigations the cereal grass (Andropogon gayanus, Panicum maximum, Pennisetum purpurea and Oryza sativa) straws were used to grow Pleurotus ostreatus var florida in view to find out whether they would be ideal for production of valuable fruit-bodies of the mushroom. The results showed that the stawsupported good yield of the mushroom that is rich in nutrients and chemical composition (tables 1 and 2). The present work is focused on determining the proximate, phytochemical, and mineral compositions of the substrates, to relate them with the yield and quality of the Pleurotus ostreatus var florida produced. The work was carried out with the perspective that grass straw are waste materials and that mushrooms they produce do significantly contribute to the minerals in the human diet, the data collected would serve as an useful basis to define the nutritional value of a given mushroom species, along with any warnings for toxic minerals, depending on their concentration.

\section{Sources of the grain straws}

\section{Materials And Methods}

The grass straws were collected as from farms at various locations in Abia State Nigeria during the respective farming season.

\section{Preparation of samples for analyses:}

The grain crop straws were sun-dried and separately chopped into tiny pieces using machetes. The separate samples were then ground into fine powder using a Corona (Landers) blender, Model Y. CIA, S.A. 0897, and sieved using two layers of cheese cloth. The sieved samples were then dispensed into clean dryspecimen bottles and stored at room temperature in the Laboratory of the Department of Plant Science and Biotechnology, Michael Okpara University of Agriculture, Umudike until required for analyses.

\section{Test for alkaloids (Harborne 1973)}

\section{Pytohemical Contents Determination: (Qualitative Analysis)}

About $5.0 \mathrm{~g}$ of the dry powdered sample of the mushroom was placed into a $100 \mathrm{ml}$ conical flask, containing $2 \mathrm{ml}$ of $5 \% \mathrm{H}_{2} \mathrm{So}_{4}$ in ethanol. The mixture was heated to boiling in a water bath, left to cool and then tested for the presence of alkaloids. Two (2) $\mathrm{ml}$ of the filtrate of the heated samples were the used to test for colour change using 2 drops of Mayer's reagent for yellow precipitate and 2 drops of Wangner's reagent for reddish-brown precipitate.

\section{Test for Flavonoids.}

Five (5) $\mathrm{ml}$ of dilute solution was added to $5 \mathrm{ml}$ of aqueous filtrate of each sample. To this mixture, about 2 drops of $\mathrm{H}_{2} \mathrm{SO}_{4}$ as added and observed for yellow colouration which would disappear on storage. (Harborne 1973)

\section{Test for tannin:}

Harborne's(1973) method was used; Dry powdered sample (5.0g) was boiled in $20 \mathrm{ml}$ distilled water in a water bath. On cooling a drop of ferric chloride was added and observed for a brownish green or a blue-black colouration.

\section{Test of saponins (Harborne 1973:}

About $2 \mathrm{~g}$ of the dry powdered sample was boiled in $20 \mathrm{ml}$ of distilled water in a bath after cooling, the boiled mixture was filterered Ten (10) $\mathrm{ml}$ of the filtrate was mixed with $5 \mathrm{ml}$ distilled water and shaken vigorously for a stable froth. Three drops of olive oil were added to the frothing solution, and the formation of an emulsion confirmed the presence of saponins.

\section{Test for phenol (Harborne 1988:}

Five (5) grams of the powdered sample was mixed with $20 \mathrm{ml}$ of tetraoxosulphate (VI) acid $\left(\mathrm{H}_{2} \mathrm{SO}_{4}\right)$ in ethanol and heated for $5 \mathrm{~min}$. filtrate of the heated mixture $(1 \mathrm{ml})$ and 2 drops of neutral ferric chloride were mixed to observed green, blue or black colouration. 


\section{Quantitative estimation of the Chemicals:}

Each value is the mean of three replicate determination \pm standard deviation.

Akaloids: Five grams (5g) of the dry powdered sample was used to determine the alkaloids contents of the mushroom following the method of Harborne (1973). The alkaloid was expressed as percentage.

$\begin{aligned} & \% \text { Alkaloids: }=\quad \text { weight of residue } \\ & \text { Weight of sample }\end{aligned} \quad \times \quad \underline{100}$

\section{Determination of Flavonoids:}

About $5 \mathrm{~g}$ of the dry powdered sample was used to determine of Flavonoids according (Boham and Kocipai, 1994). The sample was mixed with $100 \mathrm{mls}$ of $2 \mathrm{~m} \mathrm{HCl}$ at room temperature. The solution was boiled for 30min with water bath, cool and filtered. $20 \mathrm{mls}$ of Ethyl Acetate was added to the filtrate and filtered again with a weighed filter paper. The filter paper was oven dry, cool and weighed

$\%$ Flavonoids: $=\frac{\text { weight of residue }}{\text { Weight of sample }} \times \frac{100}{1}$

\section{Determination Of Tannin}

The method of Okeke and Elekwa, (2003) was used for tannin determination using $5 \mathrm{~g}$ of the sample shaken with $50 \mathrm{mls}$ of $\mathrm{H}_{20}$ and and left to stand for $30 \mathrm{~min}$. The solution was filtered and $2 \mathrm{mls}$ of the filtrates was introduced into a test tube and $3 \mathrm{mls}$ of $0.1 \mathrm{M} \mathrm{Fecl}_{3}$ and $2 \mathrm{ml}$ of potassium faro cyanide were added. Addition of $46 \mathrm{mls}$ of water was done. It was filtered again and $1 \mathrm{ml}$ of the filtrate was used to read the absorbance at $710 \mathrm{~nm}$ within $10 \mathrm{~min}$

\section{Determination of Saponins}

Saponins determination was carried out using (Harborne, 1973) method, Five (5) g of the sample was boiled with $100 \mathrm{mls}$ of $20 \%$ ethanol in a water bath for $1.30 \mathrm{~min}$ and filtered while still hot. The filtrate was collected and heated for $30 \mathrm{~min}$, in 40mls of ether then poured into a separating funnel, the lower part of the filtrate in the separating funnel was collect and $60 \mathrm{mls}$ of $\mathrm{n}$-butanol was added and the upper layer/part was collect while the lower part was discarded, the filtrate was evaporated to dryness using steam Bath at $70^{\circ} \mathrm{C}$. in an oven cooled and weighed.

\section{Determination of Phenolic Content}

The total phenol content was determined using (Harborne, 1973) method. The fat free $0.2 \mathrm{~g}$ sample was boiled for $15 \mathrm{mns}$ with $50 \mathrm{ml}$ of ether for the extraction of phenol. five $\mathrm{ml}$ of the extract was pipetted into a $50 \mathrm{ml}$ flask and $10 \mathrm{ml}$ of distilled water was added also $2 \mathrm{ml}$ of ammonium hydroxide solution and $5 \mathrm{ml}$ of concentrated amyl alcohol were added and made up to mark and left to react for 30min for colour development. The absorbance of the solution was read at $505 \mathrm{~nm}$ wave length using a spectrophotometer.

\section{Proximate Analysis}

\section{Moisture content determination}

Five grams $(5.0 \mathrm{~g})$ of the powdered dry samples was placed into clean dry glass Petri dishes of known weight. These were placed in an electric oven at $15^{\circ} \mathrm{C}$ and allowed to dry for 6-8 hours (La Guardia et al., 2005; Konuk et al., 2006, Okwulehie and Ogoke, 2013).

The oven dried sample were weighed and placed back in the oven to further dry for 1 hour. The weighing and drying was repeated until the weight became constant. The percentage moisture content was calculated as follows.

$\%$ moisture: $=\frac{\text { weight of residue }}{\text { Weight of sample }} \times \frac{100}{1}$

Ash Content

$1 \mathrm{~g}$ of the dry sample was used this value was obtained by weighing the sample before and after burning it at $500^{\circ} \mathrm{C}$ overnight.

\section{Crude fibre}

The total fibre content was determined by the Weende method (AOAC 1980) 5.0g of the sample was placed into a $250 \mathrm{ml}$ beaker and hydrolyzed by adding $20 \mathrm{ml}$ of $25 \%$ sulphuric acid and boiled under control for about $30 \mathrm{~min}$ on a hot plate. The mixture was filtered through a piece of clean white cloth then rinsed with hot distilled water. The residue was again boiled, with $50 \mathrm{ml}$ of $2.5 \%$ sodium hydroxide $(\mathrm{NaOH})$ for $30 \mathrm{~min}$, then filtered and rinsed with distilled water. The residue was finally collected and transferred into a crucible, dried in 
the oven to a constant weight. The weight of the fiber was calculated and expressed as a percentage of crude fiber as following

$\begin{array}{ll}\text { Crude fiber: }= & \text { weight of fiber } \\ \text { Weight of sample } & 1\end{array}$

\section{Protein content}

Protein content of the samples was determined by the use of the macro-kjeldahl method, protein contents were determined first and the value was multiplied by 6.25 coefficients (La Guardia et al., 2005). To determine the protein content, $1 \mathrm{~s} .0 \mathrm{~g}$ of the dry powdered sample was digested with $5 \mathrm{ml}$ of concentrated Tretra-oxosulphate (vii) acid, to which a tablet of selenium catalyst was added in a fume cupboard. The digest was made up to mark in a $250 \mathrm{ml}$. volumetric flask. Ten $\mathrm{ml}$ of the digest was distilled and titrated with $0.2 \mathrm{~N}_{2} \mathrm{SO}_{4}$. The crude protein is therefore equaled to the $\mathrm{N}$ multiplied by a conversion factor, 6.25 .

\section{Determination of Fats and Oil}

The fats and oil contents of the sample were determined following the Twisselman method using a diethyl-ether as solvent (AOAC, 1980). Five grams $(5.0 \mathrm{~g})$ of the dry mushroom sample was introduced into an ether-extracting thimble and placed on a soxhlet reflux flask connected to a round bottomed flask of known weight. This was placed on a heating marital filled with about $250 \mathrm{ml}$ of petroleum ether. The oil was extracted by a reflux system. After a series of refluxes, a clear solution was obtained in the flask, the sample was removing. Further heating separated the ether from the extraction oil. The round-bottomed flask containing the oil was finally dried in an oven of $70^{\circ} \mathrm{c}$ determination by gravimetric method was done and expressed as a percentage of the sample used, thus.

$\%$ Fat and oil $=\frac{\text { weight of fiber }}{\text { Weight of sample }} \times \frac{100}{1}$

\section{Mineral Element Determination}

The levels of the mineral elements calcium, phosphorus, sodium, magnesium, potassium and nitrogen were determined using the wet digestion extraction methods as describe by Nivozamsky et al., (1983).

\section{Heavy Metals Analysis \\ Preparation of selenium (sulfuric acid mixture for analysis).}

One (1) liter of sulfuric acid, $3.5 \mathrm{~g}$ of selenium powder were mixed and heated in a sturdy Pyrex glass container on a hot plate at high temperature until clear. The selenium was dissolved into the sulfuric acid at about $280^{\circ} \mathrm{C}$. After the selenium has dissolved, the hot plate was turn off and left until cool.

The levels of copper lead, cadmium and zinc were determined using the method of Nivozamsky, et al., (1983)

\section{Results}

The results on phytochemical, proximate, minerals and heavy metals composition of the four cereal grass straws namely: Andropogon gayanus, Panicum maximum, Pennisetum purpurea and Oryza sativa are presented $n$ Tables 1-4

The phytochemical compositions of the straws are presented in Table 2. The result shows that all the straws contain alkaloids, flavonoids, phenols, saponins and tannins in varying quantities. However, the highest percentage of alkaloids content is $.0 .19 \pm 0.02 \%$ obtained in P. purpurea. The highest content of tannins $(0.270 \pm 0.002)$ was also obtained from P. purpurea and the lowest from Oryza sativa straw. Phenols content $(0.161 \pm 0.001)$ from P. purpurea was the highest and the least $(0.041 \pm 0.007)$ was obtained from O. sativa. The saponins content ofP. purpurea $(0.37 \pm 0.014)$ was the highest and the lowest $(0.13 \pm 0.014)$ was from Panicum straw. Flavonoids contents were significantly higher in Panicum straw $(0.25 \pm 0.024 \%)$ and the least $(0.09 \pm 0.024)$ was from O. Sativa straw

The result of the proximate composition of the mushrooms is summarized in Table 1. The highest protein content of the straws was obtained from Andropogon straw with $17.74 \pm 0.47 \%$ followed by that of Oryza straw and the lowest protein occurred in Panicum straw. The fat content obtained from Andropogon straw $(1.86 \pm 0.02 \%)$ and Pennisetum straw $(1.51 \pm 0.02 \%)$ were higher than those obtained from Panicum and Oryza straws $(0.71 \pm 0.03)$ and $(0.53 \pm 0.02)$ respectively. The ash content of the Pennisetum straw was higher than that of Panicum straw which showed lowest content. Carbohydrate from Andropogon straw (30.13 \pm 0.48$)$ was significantly higher than that of Oryza straw which was the lowest. 
The result of the minerals composition of the grain straws is summarized in Table 3 . The calcium content obtained from Andropogon straw was appreciably the highest while the lowest was found in Oryza straw. Magnesium content of Andropogon and Pennisetum straws were the same $(13.6 \pm 1.39 \mathrm{mg} / 100 \mathrm{~g})$ and lower than that obtained from Oryza straw. The magnesium obtained from Panicum straw was least $(8.8 \pm 1.39$ $\mathrm{mg} / 100 \mathrm{~g})$. Sodium content was highest in Oryza straw while Phosphorus content was highest in Pennisetum (233.47 \pm 1.63$)$ and the lowest in Andropogn (158.09 \pm 0.5$)$.

The results of the heavy metals' concentrations of mushrooms are summarized in Table 4. The highest content of cadmium (7.18ppm), zinc $(25.08 \mathrm{ppm})$ lead $(8.44 \mathrm{ppm})$ and copper $(9.96 \mathrm{ppm})$, were found in Andopogon, while the least content of Lead $(0)$, copper $(1.5 \mathrm{ppm})$ and cadmium $(3.58 \mathrm{ppm})$ were found in Oryza straw. The content of cadmium, lead and copper were very low in the other straws.

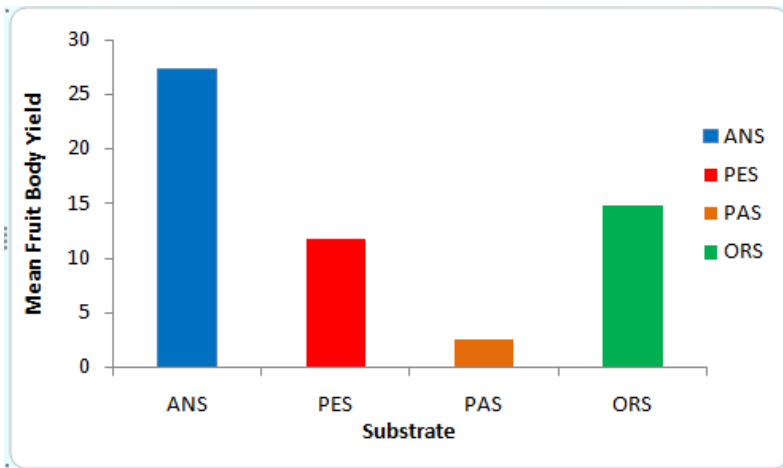

Fig. 1: Fruitbody yield of Pleurotus ostreatus var florida in different Grain-crop straws.

Source: Okwulehie and Okwujiako (2008).

Table 1a. The effects of the different substrates on the fresh weight and quality of the oyster mushroom (P. ostreatus vaflorida).

\begin{tabular}{|l|l|l|l|}
\hline Substrates & Mean fresh weight & Mean Pileus size & Mean stipe size \\
\hline Andropogen straw & $56.65^{\mathrm{a}}$ & $4.17^{\mathrm{b}}$ & $2.25^{\mathrm{a}}$ \\
\hline Panicum straw & $42.21^{\mathrm{c}}$ & $1.92^{\mathrm{c}}$ & $1.05^{\mathrm{b}}$ \\
\hline Pennisetum straw & $21.62^{\mathrm{b}}$ & $4.78^{\mathrm{a}}$ & $2.68^{\mathrm{a}}$ \\
\hline Oryza straw & $20.60^{\mathrm{b}}$ & $3.59^{\mathrm{b}}$ & $2.30^{\mathrm{a}}$ \\
\hline Total & 27.27 & 3.61 & \\
\hline
\end{tabular}

Means having the same superscript letters are not significantly different $\mathrm{P}>0.05,0.01$ by LSD.

Source: Okwulehie and Okwujiako 2008

Table 1: Proximate Composition of the Grain-crop straws (\%)

\begin{tabular}{lllllll}
\hline Straw & Fat & Protein & Moisture & Fibre & Ash & CHO \\
\hline Andropogon straw & $1.86 \pm 0.02$ & $17.74 \pm 0.47$ & $5.05 \pm 0.07$ & $40.13 \pm 0.12$ & $4.087 \pm 0.09$ & $30.13 \pm 0.48$ \\
Pennisetum straw & $1.51 \pm 0.02$ & $13.25 \pm 0.82$ & $9.33 \pm 0.02$ & $41.33 \pm 0.15$ & $5.49 \pm 0.09$ & $29.08 \pm 0.78$ \\
Panicum straw & $0.71 \pm 0.03$ & $13.07 \pm 0.22$ & $5.15 \pm 0.03$ & $49.74 \pm 1.97$ & $3.83 \pm 0.12$ & $27.49 \pm 1.61$ \\
Oryza straw & $0.53 \pm 0.02$ & $13.21 \pm 0.22$ & $5.0 \pm 0.09$ & $41.93 \pm 0.071$ & $4.49 \pm 0.098$ & $34.82 \pm 0.14$ \\
\hline
\end{tabular}

Values are means of 3 replicates \pm standard deviation.

Table 2: Phytochemical Composition of the Grain-crop straws (\%)

\begin{tabular}{lllllll}
\hline Straw & Tannins & Saponnins & Alkaloids & Phenols & HCN & Flavonoids \\
\hline Andropogon straw & $0.187 \pm 0.001$ & $0.17 \pm 0.014$ & $0.05 \pm 0.014$ & $0.080 \pm 0.007$ & $2.59 \pm 0.09$ & $0.11 \pm 0.024$ \\
Pennisetum straw & $0.270 \pm 0.002$ & $0.37 \pm 0.014$ & $0.19 \pm 0.02$ & $0.161 \pm 0.001$ & $3.92 \pm 0.05$ & $0.18 \pm 0.07$ \\
Panicum straw & $0.172 \pm 0.002$ & $0.13 \pm 0.014$ & $0.23 \pm 0.02$ & $0.169 \pm 0.007$ & $3.98 \pm 0.05$ & $0.25 \pm 0.024$ \\
Oryza straw & $0.137 \pm 0.001$ & $0.15 \pm 0.014$ & $0.05 \pm 0.014$ & $0.041 \pm 0.007$ & $2.96 \pm 0.06$ & $0.09 \pm 0.024$ \\
\hline
\end{tabular}

Values are means of 3 replicates \pm standard deviation.

Table 3: Mineral Composition of the Grain-crop straws (mg/100g)

\begin{tabular}{llllll}
\hline Straw & Calcium & Magnesium & Potassium & Sodium & phosphorus \\
\hline Andropogon straw & $305.94 \pm 2.32$ & $13.6 \pm 1.39$ & $243.7 \pm 0.5$ & $9.2 \pm 0.2$ & $159.09 \pm 0.5$ \\
Pennisetum straw & $239.14 \pm 2.32$ & $13.6 \pm 1.39$ & $224 \pm 0.4$ & $11.3 \pm 0.1$ & $233.47 \pm 1.63$ \\
Panicum straw & $219.104 \pm 2.32$ & $8.8 \pm 1.39$ & $173.1 \pm 0.54$ & $9.7 \pm 0.1$ & $161.90 \pm 2.5$ \\
Oryza straw & $203.072 \pm 2.32$ & $27.2 \pm 2.8$ & $352.3 \pm 0.23$ & $12.67 \pm 0.58$ & $198.89 \pm 0.5$ \\
\hline
\end{tabular}

Values are means of 3 replicates \pm standard deviation. 
Table 4: Heavy Metal Composition of the Grain-crop straws (ppm)

\begin{tabular}{llllll}
\hline Straw & Cadmium & Zinc & Lead & Copper \\
\hline $\begin{array}{l}\text { Andropogon } \\
\text { straw }\end{array}$ & 7.18 & 25.08 & 8.44 & 9.96 \\
$\begin{array}{llll}\text { Pennisetum } \\
\text { straw }\end{array}$ & 0.94 & 10.64 & 2.32 & 3.24 \\
Panicum straw & 0.92 & 13.3 & 0.46 & 2.58 \\
Oryza straw & 0.58 & 20.42 & 0 & 1.5 \\
\hline
\end{tabular}

Values are means of 3 replicates \pm standard deviation.

\section{Discussion}

The result of the investigations generally indicates that the grain crop straws proximately contain appreciable quantities of carbohydrates, proteins, fibre moisture and ash. As should be expected, the fat contents are low. This of course was the reason why the straws were able to support the fruit bodies of Pleurotus ostreatus produced on them by Okwulehie and Okwujiako, (2008). According to the work of Okwulehie and Okwujiako (2008), Andropogon straw yielded the highest fruit-bodies and fresh weight of Pleurotus ostreatus var florida (Fig. 1).

Analysis of the proximate composition of the straws has shown that Andropogon straw contain the highest quality of the proximate composition and minerals, followed by Oryza straw implying that, the highest number of fruit-bodies produced by Andropogon straw and then Oryza straw was as a result of the large quantity of nutrient they contain. This conforms to report by Badu et al (2012) that the yield and quality of the Oyster mushroom they produced on saw dust depended on the chemical content of the substrate used, and that Triplochiton sclenoxylon saw dust which contained more nutrients gave the best yield of the mushroom. The trend was also followed by the mineral and chemical contents of the grain straws used in the present experiment. The bioactive components of Andropogon straw were slightly lower than that of the other straws. This is of little consequence in as a factor in the choice of the straw for production of mushroom.

The highest concentration of zinc and copper in Andropogon straw could be an added factor in the richness of the straw since according to Lenntech (1993), zinc and copper are essential to maintain the metabolism of human body. However they become toxic at higher concentration. The cadmium and Lead concentrations of the straws however calls for a little caution because of bioaccumulation, otherwise the recommendation of Okwulehie and Okwujiako (2008) to use Andropogon straw as a preffered straw $\mathrm{r}$ production of Pleurotus ostreatus var florida mushroom should be upheld..

\section{References}

[1] Association of Official Analytical Chemists, AOAC. (1980). Official method of Analysis (13th Ed) Association of Official Analytical Chemists Washington D.C.

[2] Boham, A.B. and A. Ckoeipai, (1994) Flavonoids and conversed tannins from leaves of Hawallan Vacciniumvaticulatum and V. calycinium pacific Sci. 48: 458-463.

[3] Konuk, M., Afyom, A., Yagiz, D. (2006). Chemical composition of naturally growing edible mushrooms. Palldsrani Journal ofBotany38 (3): 799-804.

[4] Okwulehie, I. C. and Okwujiako, I. A. (2008). The use of Local Nigerian Substrate for the Production of Pleurotus ostreatus var florida Eger.Sporophores Dynamic Biochemistry, Process Biotechnology and Molecular Biology 2(1): 38-40 (Print ISSN 17490626)

[5] Chiejina, N. V. And Olufokunbi, J. O. (2010). Effects of different substrates on the yield and protein content of Pleurotus tuberregium. African Journal of Biotechnology 9 (11): 1573-1577.

[6] Badu, M., Twumasi, S. K. and Boadi, N. O. (2011). Effect of Lignocellulosic in wood used as Substrate on Quality and Yield of Mushrooms, Food and Nutrition Sciences 2: 780-784

[7] Okwulehie, I. C. and Ogoke, J. A. (2013). Bioactive and Heavy Metal constituents of some edible mushrooms found in Abia State of Nigeria. International Journal of Applied Microbiology and Biotechnology Research, 1-15.

[8] Fasidi, I. O. (1996). Studies on Volvariella esculenta (Muss) Singer. Cultivation on Agricultural waste, Proximate Composition of stored mushroom. Food Chemistry, 55 (2). 161-163

[9] Fasidi, I. O. And Ekuere, U. U. (1993). Studies on Pleurotus tuber-regium (Fries) Singer Cultivation, Proximate Composition Food Chemistry, 48 (2): 255-258.

[10] Okwujiako, I. A. (1992). Studies on cultivation of Pleurotus tuber-regium (Fries) Singer. Tropical Journal of Applied Sciences 2: $56-60$

[11] Okwujiako, I. A. And Smith, J. F. (1999). Producing edible Sclerotia of Pleurotus tuber-regium (Fries) Singer from wheat straw. Journal of sustainable Agriculture and Environment 1:68-72. 
[12] Lenntech, B. V. (1993). Heavy Metals. www.lenntech.com/processes/heavy/heavy-metals/heavymetals.htm

[13] Royse, D. J. (2003). Cultivationof Oyster Mushroom. Pennsylvania State University Press, Pennsylvania, 10p

[14] Sharma, B. B. (2003). Effects of different substrates (Grain straws) on Spawn growth and yield of pink oyster mushroom, Pleurotus djamor (Fr.) Boedijn. Journal of Mycology and Plant Pathology, 33(2):265-268.

[15] Edeoga H. O. \& Eriata D. O. (2001). Alkaloids, Tannin and Saponin contents of some Nigerian medicinal plants. J. Med. Aromat Plant Sci. 23:344-349

[16] Harborne, J. B. (1973). Phytochemical Methods Chapman and Hall Ltd. London, PP 11-113.

[17] Harborne J. B. (1988). Introduction of ecological biochemistry (3rd Ed). Academic Press. Harborne J. B. (1973). Phytochemical methods. Chapman and Hall Ltd. London, pp 11-113.

[18] La Guardia M., Venture G. \& Venturalla F. (2005). Chemical composition and nutritional value of Pleruotus taxa growing on umbellferous. Plants (Apiaceaes). J. Agric. Food Chem. 53:5997- 6002.

[19] Nivozamsky I., Houba, V. J. G., Van Eck R. \& van Vark, W. (1983). A novel digestion technique for multi-element plant analysis. Commun. Soil Sci. Plant Anal. 14:239-248.

[20] Okeke C. U. \& Elekwa I. (2002). Phytochemical study of the extracts of Gongronema latifolium Benth. (Asclepiadacea). J. Health Vis. Sci. 5:47-55. 